\title{
Melanoma of the Conjunctiva cTO TNM
} Finding v7

National Cancer Institute

\section{Source}

National Cancer Institute. Melanoma of the Conjunctiva CTO TNM Finding v7. NCI

Thesaurus. Code C88641.

Melanoma of the conjunctiva with no evidence of a primary tumor. (from AJCC 7th Ed.) 